\title{
Marlovian Joan la Pucelle
}

\author{
M. L. STAPLETON
}

PURDUE UNIVERSITY

The Joan episodes in 1 Henry VI have struck Shakespeareans as Marlovian from the era of the dual Victorian Fredericks, Fleay (1831-1909) and Furnivall (1825-1910), though

Marlowe scholars have not reciprocated the attention with quite the same ardor. To this end, a careful reading of the scenes that the New Oxford Shakespeare (2016) attributed to Marlowe seems entirely in order. ${ }^{1}$ No matter who actually made Joan, or whether we view her as $l a$ Pucelle or de Arc, her lineage was Marlovian. ${ }^{2}$

Commentators such as Furnivall have been vexed by the dichotomous portrayal of Joan in 1 Henry VI, a spirited, mostly virtuous enemy of the English for four acts who then in the fifth fails to motivate the demons she has summoned, renounces the shepherd claiming to be her father, and invokes pregnancy in her inability to save herself from the stake. Based on these somewhat drastic modifications in her character and mien, some have argued for her complete depravity throughout, reading her earlier scenes through the lenses of her final furor. Her first line, "Reigner, is't thou that thinkest to beguile me?" (1.2.65), could be read ironically against her, given its third verb. Henrietta Lee Palmer (1859) criticised her as a product of "the bitterest English prejudice, as half witch, half charlatan - a coarse, fighting, blood-thirsty Amazon.” E. M. W. Tillyard (1944) saw her as God's scourge for sinful England and, as woman warrior, a violation of degree, an emblem of the unnatural. David

\footnotetext{
${ }^{1}$ The New Oxford Shakespeare: Modern Critical Edition: The Complete Works, ed. Gary Taylor, Teri Bourus, Gabriel Egan, and John Jowett (Oxford: Oxford University Press, 2016). Studies that discuss the Marlovian possibilities in the Henry VI plays include Gary Taylor, "Shakespeare and Others: The Authorship of Henry the Sixth, Part One," Medieval and Renaissance Drama in England 7 (1995): 145-205; Thomas Merriam, "Tamburlaine Stalks in Henry VI," Computers and the Humanities 30 (1996): 267-91; Paul Vincent, "Structuring and Revision in 1 Henry VI," Philological Quarterly 84, no. 4 (2005): 377-402; Brian Vickers, "Incomplete Shakespeare: Or, Denying Co-Authorship in 1 Henry VI," Shakespeare Quarterly 58, no. 3 (2007): 311-57; and "Shakespeare and Authorship Studies in the Twenty-First Century," Shakespeare Quarterly 62, no. 1 (2011): 106-40; Hugh Craig, "The Three Parts of Henry VI," in Shakespeare, Computers, and the Mystery of Authorship, ed. Hugh Craig and Arthur F. Kinney (Cambridge: Cambridge University Press, 2009), 40-77; Warren Chernaik, "Shakespeare as Co-Author: The Case of 1 Henry VI," Medieval and Renaissance Drama in England 27 (2014): 192-220; Gary Taylor and John V. Nance, "Imitation or Collaboration? Marlowe and the Early Shakespeare Canon," Shakespeare Survey 68 (2015): 32-47; Santiago Segerra, Mark Eisen, Gabriel Egan, and Alejandro Ribeiro, "Attributing the Authorship of the Henry VI Plays by Word Adjacency," Shakespeare Quarterly 67, no. 2 (2016): 232-56.

${ }^{2}$ References to Shakespeare's texts follow the lineation of The Riverside Shakespeare, ed. G. Blakemore Evans and J. J. M. Tobin, $2^{\text {nd }}$ ed. (Boston, MA: Houghton Mifflin, 1997). References to Marlowe's plays and poetry follow Christopher Marlowe: The Complete Plays, ed. Mark Thornton Burnett (London: Dent, 1999) and Christopher Marlowe: The Complete Poems, ed. Burnett (London: Everyman, 2001).
} 
Riggs (1971) compared her unmasking in Act V to the stripping of Duessa in The Faerie Queene, I, xi. Benedict Nightingale (1977), reviewing a Stratford production, thought her "a witch, slut and snob, capable of spitting in her own father's face before being lugged off to a well-merited frying." Patrick Ryan (2004) characterized her depiction as "a whorish witch and conjuror, exaggerating even the English chroniclers' calumnies against her." 3 It seems not to have occurred to some commentators that Joan's Marlovian vaunting in her final scene results from terror, since the flames await. One set of men who has used her then betrays her to another who will burn her at the stake, no gunpowder necklace provided. Other voices have claimed that the portrayal was more subtle, perhaps benign. Graham Holderness (2000) found her to be "the true centre" of 1 Henry VI, "virtually undefeated" in battle until her capture, not a subject of irony. Nancy Gutierrez (1990) wrote that the portrayal "demonstrates the cultural use of gender as a value-laden metaphor descriptive of both political and moral issues: biological difference becomes the site for cultural conflict." Similarly, Phyllis Rackin (1990) thought it symbolized the conflict between England and France in a series of opposites: "masculine and feminine values; chivalric virtue versus pragmatic craft, historical fame versus physical reality, patriarchal age versus subversive youth, high social rank versus low, self versus other," nominalism versus realism. Leah Marcus and Gabriele Bernhard Jackson (1998) believed Joan a parody of Elizabeth at Tilbury or even the Queen of Scots: virago, crossdresser, strong beyond expectations, the latter concluding: 'her triumphs are based simply on boldness, common sense, and resourcefulness ... this supposed witch is the most down-to-earth pragmatist in the play."4

Untangling Joan's mingled yarn has been part of the authorship controversy concerning 1 Henry VI, one rooted in the Enlightenment. Nicholas Rowe $(1709,1714)$ and Alexander Pope $(1725,1728)$ were mute on the matter, the former emending the Folios' "Puzel" to "Pucelle" and "Acre" / "Aire" to "Arc." Lewis Theobald (1733) seems to have initiated the critical trend that has since persisted: "tho there are several Master-Strokes in

\footnotetext{
${ }^{3}$ Henrietta Lee Palmer, The Stratford Gallery: Or, The Shakspeare Sisterhood (New York: Appleton, 1859), 265; E. M. W. Tillyard, Shakespeare's History Plays (London: Chatto and Windus, 1944); David Riggs, Shakespeare's Heroical Histories: "Henry VI" and Its Literary Tradition (Cambridge, MA: Harvard University Press, 1971), 107; Benedict Nightingale, "Henry VI, Stratford," Theatre Review, New Statesman 94 (22 July 1977): 124; Patrick Ryan, "Shakespeare's Joan and the Great Whore of Babylon," Renaissance and Reformation 28, no. 4 (2004): 56.

${ }^{4}$ Graham Holderness, Shakespeare: The Histories (New York: Palgrave Macmillan, 2000), 129, 131; Nancy Gutierrez, "Gender and Value in 1 Henry VI: The Role of Joan de Pucelle," Theatre Journal 42, no. 2 (1990): 183; Phyllis Rackin, Stages of History: Shakespeare's English Chronicles (Ithaca, NY: Cornell University Press, 1990), 151; Leah Marcus, Puzzling Shakespeare: Local Reading and Its Discontents (Berkeley, CA: University of California Press, 1988), 74-90; Gabriele Bernhard Jackson, "Topical Ideology: Witches, Amazons, and Shakespeare's Joan of Arc,” English Literary Renaissance 18, no. 1 (1988): 63.
} 
these three Plays, which incontestably betray the work of Shakespeare; yet I am almost doubtful, whether they were entirely of his Writing." Edmund Malone (1790) agreed, and George Steevens (1793) did not. ${ }^{5}$ The problem has unsettled scholars and encouraged disintegrationists since the mid-nineteenth century such as Fleay, A. G. Swinburne, and Felix E. Schelling. ${ }^{6}$ In the early twentieth, the First Arden editor, Henry Chichester Hart (1909), devoted most of his introduction to adducing parallels between 1 Henry VI and the works of Robert Greene, Thomas Nashe, and George Peele. Charles Crawford's Marlowe Concordance included the three parts of Henry VI $(1911,1913,1932) .{ }^{7}$ Henry David Gray (1917) argued that Shakespeare served merely as reviser or collaborator: "no one will deny that in most of the scenes there is not the faintest evidence of his workmanship. It is certain that he left much that was crude and raw, I presume because it was theatrically effective." Greene was Gray's candidate for authorship, just as Hart had posited: "There is something Marlowesque in the opening lines and in other bits; but I think that Marlowe himself cannot be read into this drama." ${ }^{\prime 8}$ E. K. Chambers $(1924,1930)$ doubted that Shakespeare was the sole author of any of the three parts of Henry VI, but deplored the disintegrationism of his nineteenth-century predecessors. ${ }^{9}$

\footnotetext{
${ }^{5}$ Theobald continues: "And unless they were wrote by him very early, I shou'd rather imagine them to have been brought to him as a Director of the Stage; and so to have receiv'd some finishing Beauties at his hand. An accurate observer will easily see, the Diction of them is more obsolete, and the Numbers more mean and prosaical, than in the Generality of his genuine Compositions" (The Works of Shakespeare, 7 vols. (London: 1733), 4:109-10n1). Malone: "I was long struck with the evident Shakspearianisms in these plays, which appeared to me to examine such decisive weight, that I could scarcely bring myself to examine with attention any of the arguments that have been urged against his being the author of them." As for 1 Henry VI, "none of these Shaksperian passages are to be found here, though several are scattered throughout the other parts. I am therefore decisively of the opinion that this play was not written by Shakspeare" (The Plays and Poems of William Shakespeare, 10 vols. (London: 1790), 6:3-4n1). Steevens: "This historical play might have been one of our author's earliest dramatic efforts; and almost every young poet begins his career by imitation.

Shakspeare, therefore, till he felt his own strength, perhaps servilely conformed to the style and manner of his predecessors" (The Plays of William Shakespeare, ed. Steevens and Samuel Johnson, 15 vols. (London: 1793), 9:502-3).

${ }^{6}$ Frederick Fleay, "Who Wrote Henry VI?" Macmillan's Magazine 33 (Nov. 1875): 50-62; A. G. Swinburne, "The Three Stages of Shakespeare," Fortnightly Review, n.s., 19 (Jan. 1876): 25-30; Felix E. Schelling, The English Chronicle Play: A Study in the Popular Historical Literature Environing Shakespeare (London: Macmillan, 1902). His chapter is titled "The Marlowe-Shakespeare Plays," 77-97.

${ }^{7}$ Hart considered Robert Greene the true author of the first part. See The First Part of Henry the Sixth, ed. Hart (London: Methuen, 1909), vii-xxxi. Crawford doubted Marlowe's authorship, but then pointed out the presence of The Massacre at Paris and Edward II in the Shakespearean triad. See Crawford, ed., The Marlowe Concordance, Materialien zur Kunde des älteren englischen Dramas, $34 \mathrm{Bd}$. and Materials for the study of old English drama, 7 vols (Louvain: A. Uystpruyst, 1911-32), 1:vii.

${ }^{8}$ Henry David Gray, "The Purport of Shakespeare's Contribution to 1 Henry VI," PMLA 32, no. 3 (1917): 374 5.

${ }^{9}$ E. K. Chambers, "The Disintegration of Shakespeare," British Academy Annual Lecture (London: British Academy, 1924); William Shakespeare: A Study of Facts and Problems, 2 vols. (Oxford: Clarendon, 1930), 1:289-93.
} 
Yet the possibility of Marlovian contribution did not vex earlier scholars as much as the idea that Shakespeare could have been responsible for such a problematic historical drama, with a woman's part the second-largest. ${ }^{10}$ The portrayal of Joan entered the historical discussion at this point and become part of the controversy. Gray believed 1 Henry VI to be a mostly Shakespearean revision of the mysterious 'harey vj' that had appeared in Philip Henslowe's Diary for 1591-3. (The New Oxford editors have, accordingly, retitled 1 Henry VI as Harry the Sixth.) ${ }^{11}$ To him, "such good stuff as this" proved its quality in part by its treatment of Joan "with a fair amount of dignity and respect." Greene's baleful influence could be seen in her last appearance (5.4), "where she is shown as contemptible and vile."12 Schelling (1902) was of the same mind: her "career is in the end distorted into that of a witch whose converse with evil spirits and whose loose life and denial of her own father go far to explain if not to justify the terrible fate that overtook her." ${ }^{\prime 13}$ Nearly four decades earlier, the genial and eccentric Furnivall had said much the same thing in his preface to the Leopold Shakspere, his English-translated version (1877) of the edition by the great German scholar Nicholas Delius (1856). The first Henry VI, "broken and choppy to an intolerable degree," could have had as many as four authors, including Marlowe. Yet Shakespeare could not possibly have been responsible for "the abominable way in which Joan of Arc is treated by Frenchmen as well as English. Traditional as the witch-view of Joan of Arc was in Shakspere's time, one is glad that Shakspere did not set it forth to us." George Bernard Shaw wrote Saint Joan (1923) as an antidote to 1 Henry VI, which was, he claimed, originally intended to portray the character sympathetically, but Shakespeare's company insisted that "unless he at once introduced all the old charges against Joan of being a sorceress and a harlot, and assumed her to be guilty of all of them, his play could not be produced."14

Furnivall was not only a founder of the Early English Text Society, the New Shakspere Society, and the Oxford English Dictionary, but also an innovator of the sport derivative from rowing known as sculling. He, in fact, helped design early sculls. His Dictionary of National Biography entry says that he undertook the sport "with his usual

\footnotetext{
${ }^{10}$ Joan appears in ten scenes $(1.2,5,6 ; 2.1 ; 3.3 ; 4.7 ; 5.2,3,5)$. Talbot speaks the largest number of lines (406), followed by Joan (254), who outdistances Plantagenet (184), King Henry, the title character (179), Suffolk (174), and Charles the Dauphin (133). See Marvin Spevack, ed., A Complete and Systematic Concordance to the Works of Shakespeare, 9 vols (Georg Olms: Hildesheim, West Germany, 1968-80), 1:179, 638, 649, 684, 680.

${ }^{11}$ Henslowe's Diary, 2 vols., ed. W. W. Greg (London: A. H. Bullen, 1904), 1:xxii, 13-16.

${ }^{12}$ Gray, "The Purport of Shakespeare's Contribution to 1 Henry VI," 381.

${ }^{13}$ Schelling, The English Chronicle Play, 78.

${ }^{14}$ Schelling, The English Chronicle Play, 78; The Leopold Shakspere, ed. Frederick James Furnivall (London: Cassell, Petter, and Galpin, 1877), xxxviii; George Bernard Shaw, Saint Joan: A Chronicle Play in Six Scenes and an Epilogue (London: Constable, 1924), xxvii.
} 
boyish enthusiasm, for it brought together two of his favourite activities: vigorous outdoor exercise and enjoyment of the company of young women." ${ }^{15}$ Lest we suspect Dr Furnivall to have been impure of heart, it should be observed that as a Christian Socialist, he was a vociferous advocate for women's rights, education, and exercise. He founded the Hammersmith Sculling Club for working-class girls and women, still in existence, now named in his honor. And he encouraged young women to pursue scholarship. Some of this perspective invaded his critical pronouncements, and perhaps not for the worse.

Furnivall's dismay at the "abominable" treatment that the Joan of 1 Henry VI received suggests that he thought of her as a real person in need of gentlemanly encouragement and nurturing, very much like Jane Lee, whom he praised highly for her analysis of 2 and 3 Henry $V I$, which appeared in the published proceedings of the New Shakspere Society (1876):

never before has the question been so ably and thoroughly handled... On the points on which Miss Lee differs from me, let the reader trust her and not me, till he has workt enough to form an opinion of his own. She has workt at the plays twenty times as much as I have, and has got a certainty about them that I can't pretend to have. ${ }^{16}$

Lee argued for full collaboration between Shakespeare and Marlowe in these plays, fifteen years before the first Oxford Shakespeare by W. J. Craig (1891), not to mention the New Oxford of today. Though she did not discuss Joan, many of her exercises in Marlovian detection regarding 2 and 3 Henry VI by way of the parallel passage method anticipated those claims by the New Oxford attributionists with their big data and function-word-clusters. For 1 Henry VI, they assigned Act 5 to Marlowe. The results of the two methodologies are the same, though some would consider one approach intellectually untenable. An advocate of the newer and more generally approved method derides work such as Lee's as “aimless" and "old-fashioned parallel hunting." 17

As Desdemona said to her father, I feel a divided duty. Let me say that I do not care one bit who wrote what. I find attribution study in any age to be the equivalent of a fool's

\footnotetext{
${ }^{15}$ William S. Petersen, "Furnivall, Frederick James," Oxford Dictionary of National Biography, online ed. (2004; rev. Oxford University Press, 2007).

${ }^{16}$ Furnivall, Leopold Shakspere, xxxviii, n3. Lee's presentation of her findings is "On the Authorship of the Second and Third Parts of Henry VI, and Their Originals," The New Shakspere Society's Transactions, 1875-6 (London: Trübner and Co., 1876), 219-79.

${ }^{17}$ MacDonald P. Jackson disdains what he terms "parallel hunting" as "aimless" and "old-fashioned," which "could have only one end result - the display of a certain number of similarities in phrasing between the target text and the works of" the hunter's "favoured candidate." "Mere similarities between play X and the canon of playwright A, even though striking, cannot alone establish a probability that playwright A wrote play X. A compelling case requires that the hypothesis of playwright A's authorship be tested by more rigorous methods." See "One-Horse Races: Some Recent Studies," in The New Oxford Shakespeare Authorship Companion, ed. Gary Taylor and Gabriel Egan (Oxford: Oxford University Press, 2017), 33, 51, 59.
} 
errand, one that I must admit to having undertaken myself. At the same time, I would be delighted to have the Marlowe canon expanded. Or, better yet, I would be pleased to have our understanding of Shakespeare's Marlovianism enlarged, building on the great work of my predecessors besides Furnivall and Lee: F. P. Wilson, Harry Levin, Nicholas Brooke, Irving Ribner, Harold F. Brooks, David Riggs, Marjorie Garber, Muriel C. Bradbrook, Kenneth Muir, James Shapiro, Robert A. Logan, Laurie Maguire, and Emma Smith, to name a few. ${ }^{18}$ Joan represents an unexplored portal between Shakespeare and Marlowe: the sole work of either, the result of a collaboration, or one playwright writing in the mode of the other.

Without taking sides unnecessarily, or discrediting the methods of the New Oxford edition, I would offer in response the reading method proposed by Maguire and Smith in their exploration of Marlowe's presence in The Tempest, since it approximates my own when I have detected the mode of one writer in the work of another and wish to analyse the phenomenon. They usefully observed that Stephen Greenblatt's notorious “elephants' graveyard" comment about source study necessitates a re-evaluation: "perhaps the blockage is in our limited practical understanding of what a source might be." Such approaches would benefit from cognitive theory, memories, and distortion, they suggest, and, just as significant, they observe that a source text might not always be obtrusively visible in its target, but hidden. ${ }^{19}$ It could also be said that this theory accords with the lessons that the humanist schoolmasters passed along to their pupils. In early modern imitation theory as advanced by Roger Ascham and Petrarch, concealment was paramount, just as Ovid says of his

\footnotetext{
${ }^{18}$ F. P. Wilson, Marlowe and the Early Shakespeare (New York: Oxford University Press, 1953); Harold Levin, The Overreacher: A Study of Christopher Marlowe (Cambridge, MA: Harvard University Press, 1952); Nicholas Brooke, "Marlowe as Provocative Agent in Shakespeare's Early Plays," Shakespeare Survey 14 (1961): 34-44; Irving Ribner, "Marlowe and Shakespeare," Shakespeare Quarterly 15, no. 2 (1964): 41-53; Harold F. Brooks, "Marlowe and Early Shakespeare," in Christopher Marlowe, ed. Brian Morris (London: Benn, 1968), 65-94; Riggs, Shakespeare's Heroical Histories; Marjorie Garber, "Marlovian Vision / Shakespearean Revision," Research Opportunities in Renaissance Drama 22 (1979): 3-9; M. C. Bradbrook, "Shakespeare's Recollections of Marlowe," in Shakespeare's Styles: Essays in Honour of Kenneth Muir, ed. Philip Edwards, Inga-Stina Ewbank and G. K. Hunter (Cambridge: Cambridge University Press, 1980), 199204; Kenneth Muir, "Marlowe and Shakespeare," in "A Poet and a Filthy Play-maker": New Essays on Christopher Marlowe, ed. Kenneth Friedenreich, Roma Gill, Constance B. Kuriyama (New York: AMS Press, 1988), 1-12; James Shapiro, Rival Playwrights: Marlowe, Jonson, Shakespeare (New York: Columbia University Press, 1991); Robert A. Logan, Shakespeare's Marlowe: The Influence of Christopher Marlowe on Shakespeare's Artistry (Burlington, VT: Ashgate, 2007); Laurie Maguire and Emma Smith, "What Is a Source? Or, How Shakespeare Read His Marlowe," Shakespeare Survey 68 (2015): 15-31.

${ }^{19}$ Maguire and Smith invoke trauma theory to explain how Shakespeare recalls Marlowe, especially Dido, Queen of Carthage in The Tempest: "it shares the qualities psychologists attach to traumatic memory: intrusive, detailed, multi-sensory recollections of the stressor; disturbed or partial recall, often unbidden; false or fictive associated memories with a similar affect," in "What Is a Source?," 25. Greenblatt's aperçu first appeared in "Shakespeare and the Exorcists," in Shakespeare and the Question of Theory, ed. Patricia Parker and Geoffrey Hartman (New York: Routledge, 1985), 163. Greenblatt excised it when his essay appeared as a chapter in Shakespearean Negotiations (Oxford: Oxford University Press, 1988), 94-128.
} 
Pygmalion: "ars adeo latet arte sua" [so did his art conceal his art] (Metamorphoses, 10.252). ${ }^{20}$ Colin Burrow suggested that "inspired misremembering," or "misremembering and mislearning" can be just as much a species of imitatio as that advanced in The Scholemaster (1570). ${ }^{21}$

Commentators who have noted rather than investigated Joan's Marlovian leanings have nonetheless made inroads into the subject. John D. Cox (1993) and Maurice Charney (1997) located her rhetoric in Tamburlaine. ${ }^{22}$ Hugh Craig (2009) posited that her seemingly radical behavioural shift in the middle of 1 Henry VI makes more sense if one sees her as solely that playwright's creation: "Her alliance with fiends and witches, her scoffing rhetoric, her acting under disguise, are then those of a Marlovian villain." As for the change, "her abrupt descent into witchcraft and fornication" evokes Faustus. ${ }^{23}$ The suggestion of Maguire and Smith that broader and subtler analogies between texts might be more revealing than verbal parallels and function words, however useful these methods have proven to be, merits emulation for the purpose of discovering the Marlowe canon echoing in the Joan of 1 Henry VI.

Joan's vaunting, boasting, and self-promotion find a clear parallel in Tamburlaine. The Scythian shepherd's egotism manifests itself in virtually every speech in his ten-act dramatic chronicle, such as his fleering comment to Mycetes about his crown: "Here, take it for a while: I lend it thee." These numerous performances tend to begin with condescension, progress to a promise of action, and then conclude with self-promotion. Once the king sees the invading force, "Then shalt thou see me pull it from thy head: / Thou art no match for mighty Tamburlaine" (1 Tamburlaine, 2.4.38, 40-41). Joan's version of this speech act features the same components, yet delivered in a less static, more demonstrative way, such as battling with Talbot, "O'ertake me, if thou canst; I scorn thy strength" (1 Henry VI, 1.5.35), or promising to be the saviour of her nation: "Assign'd am I to be the English scourge. / This night the siege assuredly I'll raise" (1.2.129-30). The woman warrior, played by a boy actor, might have reminded audiences of the notorious theatrical conqueror. Her uncanny, perhaps amusing resemblance to the Alleyn characterisation suggests that the playwright employed elements of parody and tribute in his conception and execution of this history.

\footnotetext{
${ }^{20}$ P. Ovidi Nasonis Metamorphoses, ed. Richard J. Tarrant (Oxford: Clarendon Press, 2004), 292.

${ }^{21}$ Colin Burrow, "Shakespeare and Humanistic Culture," in Shakespeare and the Classics, ed. Charles Martindale and Tony B. Taylor (Cambridge: Cambridge University Press, 2004), 14.

22 John D. Cox, "Devils and Power in Shakespeare and Marlowe," Yearbook of English Studies 23 (1993): 4664; Maurice Charney, "The Voice of Marlowe's Tamburlaine in Early Shakespeare," Comparative Drama 31 (1997): 213-23.

${ }^{23}$ Craig, "The Three Parts of Henry VI," 67.
} 
In turn, this overstated self-assertion informs the persuasiveness, rhetorical inventiveness, and facility in blank verse for the two roles. Russ Macdonald observed that Marlowe tended to chisel his mighty lines of blank verse into epigrammatic, self-contained distiches such as one sees in Tamburlaine. ${ }^{24}$ This would have been a natural compositional transference for him to have made, since he worked in the couplet form in the Elegies and Hero and Leander. It could be observed that the hero's speeches suggest that the author had learned enough about the form to employ a gradual relaxation of the strictness that the rhyming distich demands of its users. Tamburlaine, ever boastful, seeks to help Mycetes's brother Cosroe visualise the effect that his invading army will have on those who behold the spectacle:

Our quivering lances, shaking in the air, And bullets, like Jove's dreadful thunderbolts, Enroll'd in flames and fiery smouldering mists, Shall threat the gods more than Cyclopian wars; And with our sun-bright armour, as we march, We'll chase the stars from heaven, and dim their eyes That stand and muse at our admired arms. (1 Tamburlaine, 2.3.18-24)

In his dramatic blank verse, Marlowe had learned to employ the prosodic effects of lyric or narrative. Here, he thought that the promise of martial prowess called for the grand style. The twenty-odd sibilants suit the description of flames hissing and thunderbolts whistling.

Alliteration emphasizes the elements in each line that require pairing and echoes the sounds of war: "bullets" and "bolts," "flames" and "fiery." Long vowels allow for a sonorous authority that link words which, again, belong together: "admired," "bright," and "eyes"; "chase," "shaking," and "flames." Though each line requires a brief pause and Marlowe only enjambs one, there are no complete stops, creating a rolling effect so that the unlikeliness of a pitiless yet poetical megalomaniac generally does not register, an attempt to charm and conquer the audience's ears along with those of Cosroe's court.

Joan's prosody in 1 Henry VI flows in a similarly Marlovian direction, with like rhetorical creativeness animating blank verse, and vice versa. Hers, however, seems more suited to a less imposing figure, a woman who dares to don a man's armour and whose journey to legitimacy contains many more impediments than her Scythian predecessor must endure. Joan's speeches seem like miniature versions of Tamburlaine's, more compressed and less discursive, perhaps a convenience designed to help the boy player and to provide a

\footnotetext{
${ }^{24}$ Russ Macdonald, "Marlowe and Style," in The Cambridge Companion to Christopher Marlowe, ed. Patrick Cheney (Cambridge: Cambridge University Press, 2004), 55-69.
} 
slightly satirical response to theatrical verbosity grown notorious. Her truest poetry is her most feigning:

Look on thy country, look on fertile France,

And see the cities and the towns defaced

By wasting ruin of the cruel foe.

As looks the mother on her lowly babe

When death doth close his tender dying eyes,

See, see the pining malady of France;

Behold the wounds, the most unnatural wounds,

Which thou thyself hast given her woeful breast.

O, turn thy edged sword another way;

Strike those that hurt, and hurt not those that help. (3.3.63-72)

Joan's male aristocratic mates had persuaded her to fashion such a splendid example of persuasion, model imprecation and exhortation in order to entice Burgundy to return to France's side and thereby weaken the English horde. With some of the same methods Tamburlaine used to frighten his adversaries with his military threats, she disguises her hollowness with sweet sounds that depend on semi-anaphoric repetition, pairs, and long vowels in the attempt to arouse pity. "Look on," "See," "wounds," and "France," culminating in the chiasmus of "hurt," appropriately and ironically, in the last line cited. Her twenty-odd sibilants, rather than evoking the sounds of battle, encourage a soothing empathy. No real enjambment occurs, but just as Tamburlaine's flowing lines mask the unlikeliness of a person such as himself delivering them, Joan's wonderful stream of verbiage distracts its hearers from the small chance that a shepherd's daughter, however divinely inspired, could produce it. "Either she hath bewitch'd me with her words, / Or nature makes me suddenly relent" (5859), remarks Burgundy. "I am vanquished; these haughty words of hers / Have batter'd me like roaring cannon-shot" (78-9).

Joan's skill in forging her identity with rhetorical acumen partakes of similar figures such as Barabas, Gaveston, Guise, and the speaker in the Elegies with his "ambitious ranging mind" (2.4.48). The metamorphic phenomenon could be described as appropriately Ovidian. She succeeds in recreating herself by designing an androgynous, providentially religious self in order to function in a masculine world hostile to her:

I am by birth a shepherd's daughter, My wit untrain'd in any kind of art. Heaven and our Lady gracious hath it pleased To shine on my contemptible estate. $(1.2 .72-75)$ 
Of shepherd origins like Tamburlaine, Joan claims that the Virgin herself divinely infused her with "That beauty I am blessed with" (86), the gift of prophecy and divine knowledge. The later jarring interlude with the ludicrously unresponsive Fiends (5.3) suggests the opposite source of supernatural powers, contradicting this claim to holiness. Yet that scene features no shortage of rhetorical inventiveness as she reacts to their appearance, silence, impotence, denial of her, and exit: “This speedy and quick appearance argues proof / Of your accustom'd diligence to me' (8-9); "hold me not with silence over long" (13); "Cannot my body nor blood sacrifice / Entreat you to your wonted furtherance?" (20-21); "See, they forsake me" (24). Some commentators have misread the body and blood reference as sexual rather than a profane reversal of the Eucharist. Though Joan changes radically and is not dishonest with herself, some lines ring ironically, such as the sneering aside about Burgundy's conversion: "Done like a Frenchman: turn, and turn again!" (3.3.85). In this, she resembles the Elegies lover, the Sulmonian parvenu come to Rome with its worldly Corinnas, their easily-deluded husbands, and their peevish refusals to be adulterously faithful to him. In his attempts to make himself over into a sophisticate, he similarly claims innocence and then demonstrates, as Joan does, that he was never capable of such a state: "My spotless life, which but to gods gives place, / Naked simplicity, and modest grace" (1.3.13-14); "I cannot rule myself but where Love please / Am driven like a ship upon rough seas" (2.4.7-8); "Would I my words would any credit bear" (3.11.20). Yet his poeticising in the same elegy suggests that they bear plenty of credit: "Poets' large power is boundless and immense" (41). His rhetorical ingenuity, resourcefulness, and imagination, like those of the Maid of Orleans, allow him to reinvent himself as well.

Marlowe's practice of actualising male androgyny, with no precise parallel to Joan's, featured an element of gender reversal that differed from Shakespeare's usual comic realization of the convention. In breeches parts such as Viola and Rosalind, boy actors professed to be women who, in turn, pretended to pretend to be the young men they actually were. Marlowe, not a writer of comedy, removed one step and reversed another so that male characters explore their feminine interiority, sometimes in same-sex relationships, and not often without difficulty. Examples abound. Fashioning himself as a conventional mistress, Ganymede upbraids Jupiter for allowing Juno to abuse him and seeks justice: "Grace my immortal beauty with this boon, / And I will spend my time in thy bright arms." Venus disapprovingly reads this relationship as transgender, criticizing the king of the gods for "toying there / And playing with that female wanton boy" (Dido, Queen of Carthage, 1.1.21$22,50-51)$. In a different incarnation of this dynamic, the narrator of Hero and Leander 
imagines Jove admiring the body of the poem's protagonist "as straight as Circe's wand," with a neck as desirable "as delicious meat is to the taste" $(61,63)$, food metaphors usually associated with heterosexual pursuit. In addition, he dramatises Neptune acting on his desires when he first mistakes Leander for Ganymede, that youth trying to swim away from this boyloving sea divinity. Hero's love reads this unwanted attention as feminising, which suggests that the reader should understand Jove's earlier prandial admiration the same way: "You are deceived, I am no woman, I" (676). Gaveston's vision of masques features “a lovely boy in Dian's shape, / With hair that gilds the water as it glides, / Crownets of pearl about his naked arms" (Edward II, 1.1.60-62). Though Mortimer Senior makes a similar projection about the hated favourite in explaining the attachment's ephemerality to his nephew, he does not describe it as a virtue, but as an inconvenience: "The mightiest kings have had their minions" (1.4.390). David H. Thurn and others have argued that Edward II emphasises the corrosive effect that the bond has on the kingdom and social order. Gaveston in essence replaces Isabella on her throne in turning the king against her, making him as "Frivolous and feminine" as himself. ${ }^{25}$ In a variation on this authorial theme, Tamburlaine justifies his monstrous act of murdering his peace-loving son Calyphas by deriding him as "this effeminate brat" whose corpse deserves burial by the hated Turks, not any of his own common soldiers, since doing so would "defile / His manly fingers with so faint a boy" (2 Tamburlaine, 4.2.164-66). Marlowe infuses androgyny with peril.

Joan's gender ambiguity obviously differs from that of Gaveston and Ganymede: female, an armed enemy to the English, a wonder to the French, but not one who menaces by desire. She presents herself as asexual to the besotted Charles: "I must not yield to any rites of love, / For my profession's sacred from above" (1 Henry VI, 1.2.113-14). As Jackson demonstrated at length, the homiletic literature of the sixteenth century praised Amazons and women warriors of classical and Biblical antiquity, so theatrical audiences might have recognized Joan as this type. Yet the representation itself in 1 Henry VI must have been sensational to the same viewers, since nothing like her had ever appeared onstage. ${ }^{26}$ She renounces conventional femininity: "My courage try by combat, if thou darest, / And thou shalt find that I exceed my sex" (89-90). In asserting herself to the dauphin and the remaining male cohort, she assumes the masculine role while reminding him of her womanhood. In spite of her peasant status, she addresses the aristocrats in the familiar

\footnotetext{
${ }^{25}$ David H. Thurn, "Sovereignty, Disorder, and Fetishism in Marlowe's Edward II," Renaissance Drama 21 (1990): 131.

26 Jackson, "Topical Ideology," 49-54.
} 
second-person singular rather than the expected and more respectful plural. Jackson also observed that in speeches such as these, Joan can hardly be described as a crude and stupid caricature, but rather as Elizabeth was, a virago, a woman strong beyond expectations, with the root in the Latin "vir" (man). Therefore, that Joan partakes of the Amazon, woman-inarms, witch, and cross-dresser does not necessarily demonize her. ${ }^{27}$ The lovestruck Charles still appreciates her prowess: "Stay, stay thy hands! thou art an Amazon / And fightest with the sword of Deborah" (1.2.104-5). Talbot, the doomed hero of the play, discovers himself obliged to conclude likewise, somewhat more grudgingly. Having heard of the Maid's prowess, he shouts, "Devil or devil's dam, I'll conjure thee: / Blood will I draw on thee, thou art a witch" (1.5.5-6), then vows, "I will chastise this high-minded strumpet" (12). Finding himself vanquished, he returns to his original diagnosis of sorcery: "My thoughts are whirled like a potter's wheel; / I know not where I am, nor what I do; / A witch, by fear, not force, like Hannibal" (19-20). Her responses consist of masculine boasting and mockery: "Come, come 'tis only I that must disgrace thee" (8). In the world of 1 Henry VI, female androgyny becomes spectacle, performance, and threat.

Marlowe undermines the stature and credibility of his major dramatic figures, an Ovidian tendency that reappears in Joan. In the Elegies, the lover no sooner consummates his love for Corinna, "Conquered Corinna in my bosom lays"; "I . . won the field and wear her" $(2.12 .2,13)$, than she aborts the ensuing pregnancy: "rashly her womb's burden she casts out" (2.13.1); "With cruel hand why dost green apples pull?" (2.14.24). The playwright makes the doomed and soon-to-be-vanquished Tamburlaine nearly ridiculous in his last scene. Near death, he insists on riding in his chariot drawn by the kings of Natolia and Jerusalem (2 Tamburlaine, 5.3.41), just as he did so triumphantly in the previous act with the kings of Soria and Trebizond: "Holla, ye pampered jades of Asia!" (5.3.1). That the Physician tries to dissuade the desiccated conqueror from battle by discussing the hypostasis (deposits) in his urine, "thick and obscure," injects a tinge of banality, reducing him to a mundane and pathetic figure who, nevertheless, keeps ranting (5.3.82-83). His continually expanding pronouncements of his own infallibility underscore exactly how fallible he has grown to be. In Faustus, Marlowe reduces the hero and his aspirations to clownishness more emphatically and more often in his use of, appropriately, clowns such as Robin and Wagner. For example, Faustus relishes what he believes to be his ability to command Mephistopheles to perform feats for him: "By him I'll be great emperor of the world" (Doctor Faustus, 1604,

\footnotetext{
27 Jackson, 41, 44, 49.
} 
1.3.106). And in the next scene, Robin and Wagner re-enact the same dynamic, parodying that relationship. The former asks, "If I should serve you, would you teach me to raise up Banios and Belcheos?" The latter responds, "I will teach thee to turn thyself to anything, to a dog, or a cat, or a mouse, or a rat, or anything” (1.4.62-65). Robin next confesses he would prefer to be turned into a flea for the purpose of investigating wenches' plackets, foretelling Faustus's desire for a wife and paean to Helen of Troy. Yet Wagner's initial reply suggests just how ordinary the clown's wishes, and by extension the hero's, actually are. The great "privilege" of compelling spirits to do his bidding results in nothing more profound than the acquisition of useless wealth and the ability to play pranks on the Pope and Holy Roman Emperor. Bartering away his immortal soul in effect reduces Faustus to the dog, cat, mouse, or rat Wagner promises Robin he might become. Perhaps Shakespeare had this line in mind in his dying king's last speech over the body of his youngest daughter: "Why should a dog, a horse, a rat have life, / And thou no breath at all?" (King Lear, 5.3.312-13). One Cordelia might be worth ten Faustuses.

Joan's subtler attenuation occurs in a scene many commentators ignore, perhaps just as problematic as the failure with the fiends and the attempts to talk her way out of her fated execution in Act V. As the French survey the corpses of the Talbots, father and son "inhearsed" (1 Henry VI, 4.7.45) in one another's arms, the playwright distinguishes between one type of perspective, embodied by the Bastard of Orleans and Joan, and its opposite, personified by Charles and Burgundy. The Bastard makes a typically ignoble sexual reference to describe the son's prowess in the field: "How the young whelp of Talbot's, raging-wood, / Did flesh his puny sword in Frenchmen's blood" (35-36). He then knavishly suggests shaming the dead: "Hew them to pieces, hack their bones asunder" (47). Charles nobly recoils: "O, no, forbear! for that which we have fled / During the life, let us not wrong it dead" (49-50). Perhaps he shares the estimate of Burgundy, who knew the son along with the father: "Doubtless he would have made a noble knight" (44). Sir William Lucy, whom the French have allowed in their camp via herald to collect the bodies of the blueblooded, shows similar reverence in listing the many titles of Talbot père, "the great Alcides of the field" (61-72). Here Joan seems to lose her stature since she sounds more like the Bastard than her reverent, magnanimous betters who have rightly praised her prowess and patriotism: "Here is a silly stately style indeed!," worse than that of a "tedious" Turk: "Him that thou magnifiest with all these titles / Stinking and fly-blown lies here at our feet" $(72,75-6)$. She then repeats her least dignified word, which suggests a baseness not heretofore apparent: "For God's sake let him have 'em; to keep them here, / They would but stink, and putrefy the air' (89-90). 
However, her true diminution occurs somewhat earlier in the same scene, again by her own words. She recounts her initially eloquent and erotically charged challenge to Talbot fils, "“Thou maiden youth, be vanquish'd by a maid"," which receives short shrift from him "with a proud majestical high scorn," specifically: "'Young Talbot was not born / To be the pillage of a giglot wench"' (38-41). Though he admits that he could be vanquished by a wench as light as herself, he thinks her for this reason too base to engage: "He left me proudly, as unworthy fight" (43). Could this be the point of the scene? Might she be unworthy after all?

Marlowe has rarely been accused of writing women well, with the exception of Isabella, Edward's queen, whom Gaveston displaces and whose role he usurps. In her unfortunate alliance with Mortimer Junior, she resembles Joan in some respects, becoming woman warrior and enabling mistress simultaneously. Yet this second, unspoken role remains primary to Isabella's handler, who undercuts her whenever she asserts herself. She eloquently addresses the troops and grandees who have arrived to help her secure the kingdom from her deposed husband on civil wars, "their sides / With their own weapons gored," the fault of "Misgoverned kings" who have caused "all this wrack" whose "looseness" has "made the channels overflow with blood" (Edward II, 4.4.6-12). In what we might now describe as a typically aggressive male speech act, Mortimer Junior interrupts her in a most insulting manner: "Nay, madam, if you be a warrior, / You must not grow so passionate in speeches" (14). Accusing her of womanly histrionics, he then patronisingly takes over the role of orator and addresses the assembly himself. Similarly, when Joan introduces herself as a savior to the fumbling French host, they condescend to her though she promises, then proves, that she exceeds her sex as a combatant. Reignier addresses her as "Fair maid," Charles vows before his defeat to her in the lists, "I fear no woman," and Alanson comments to his peers, "These women are shrewd tempters with their tongues" (1 Henry VI, 1.2.64, 102, 123). The very men who secretly despise Isabella and Joan because they fail to fulfill the banal patriarchal notions of womanliness deceive them into trying to prove themselves worthy of the masculine power and respect that they can never, as a result, earn.

Though in some respects, Act 5 seems most Marlovian of all, the aura of the playwright himself or that of his Stratford contemporary who so admired and emulated him, the scenes feature several phrases that appear repeatedly in the Shakespeare corpus. Faustian Joan occupies the first half of Scene 3 with her finely-crafted phrases: "Changed to a worser shape thou canst not be" (5.3.36); "I prithee give me leave to curse awhile" (43). And at her departure, the initial appearance of Suffolk and the guileless Isabella, reminiscent of the Mortimer Junior and Isabella alliance in Edward II, finishes the episode. As the triumphant 
York mocks the captured Joan, "Damsel of France, I think I have you fast," he probably wrenches her by the hand while they exchange unpleasantries and then exit together with her as prisoner, followed by the Folio stage direction, "Enter Suffolk, with Margaret in his hand," after which Suffolk arrogantly assures the soon-to-be queen, "Be what thou wilt, thou art my prisoner," and then in the extraordinarily specific stage direction, "Gazes on her" to underscore his sexual interest that he unsuccessfully sublimates $(5.3 .30,45)$. In this tableau, the implied equation between these complementary figures suggests that Margaret, like Joan, will be conquered and dominated, but that she too represents a virago in arms whose captor will not long survive her. Just as Mortimer promises Isabella, "Be ruled by me, and we will rule the realm" (Edward II, 5.2.5), Suffolk concludes 1 Henry VI with his boast to the audience, "Margaret shall now be Queen, and rule the King; / But I will rule both her, the King, and realm" (1 Henry VI, 5.5.107-8). Earlier, this same earl who will find himself headless in the sequel either anticipates or echoes Shakespeare when he says of Anjou's daughter: "She's beautiful; and therefore to be woo'd; / She is a woman, therefore to be won' (5.3.78-79):

Gentle thou art, and therefore to be won, Beauteous thou art, therefore to be assailed; And when a woman woos, what woman's son Will sourly leave her till she have prevailed? (Sonnet 41, 5-8)

Though many understandably regard the Sonnets as chiefly homoerotic, the young man who serves as object ironically seems to prefer women, since that appears to be the extent of his specifically sexual activity as that sequence portrays it, an urge just as ardent as Suffolk's amorous gaze at Margaret's form.

Similarly, the last two Marlowe-inflected scenes of 1 Henry VI contain yet more phrases usually associated with Shakespeare. The mocking York continues his hectoring of Joan by referring to Charles, one of her three aristocratic patrons to whom she in terror attributes a likely false paternity as "a proper man" (5.3.37), an epithet that Desdemona and Iago use to describe the handsome Lodovico and Cassio, respectively (Othello, 5.3.35; 1.3.392). Perhaps a touch of the Dauphin's nether lip merits a barefoot trek to Palestine. Though Marlowe never uses this adjective-noun pairing, "proper" surfaces nine times in his works. ${ }^{28}$ Before the peasant claiming to be her father churlishly renounces her because she denied she was "the first fruit" of his "bach'lorship," a "collop" of his flesh, the old shepherd

\footnotetext{
${ }^{28}$ Mario A. DiCesare and Robert J. Fehrenbach, eds, A Concordance to the Plays, Poems and Translations of Christopher Marlowe (Ithaca, NY: Cornell University Press, 1982), 1002-3.
} 
initially waxes loving and sympathetic, her pending execution grieving him: "this kills thy father's heart outright" (1 Henry VI, 5.4.13, 18, 2). This expression appears at least seven other times in the Shakespeare canon, most notably when Mistress Quickly says of the dying Falstaff, "the King hath kill'd his heart” (Henry V, 2.1.79), and Rosalind exclaims to Celia about Orlando as he enters their lines of vision: "O ominous! he comes to kill my heart" ( $A s$ You Like It, 3.2.246). ${ }^{29}$ As it happens, Catherine de Medici turns the same phrase in The Massacre at Paris, "O say not so, thou kill'st thy mothers heart" (13.4), when her son Charles IX mentions the "gripping pain" in his heart, "the messenger of death" (2-3), just before his passing away. It can be difficult to ascertain whether Marlowe intends any Mistress Quickly-style empathy or sincere maternal concern the audience should internalize, given his tendency to demonize her faction, especially the macabre murderousness of the Guise whose gleefully-executed atrocities she supports. The father of Clarence, Gloucester, and the future Edward IV continues savaging Joan, Guise-style: "Take her away, for she hath liv'd too long, / To fill the world with vicious qualities" (1 Henry VI, 5.4.34-35). This hyperbolic metaphor of volume shows up twice more in Shakespeare, once in the same play about Talbot, "whose glory fills the world with loud report" (2.2.43), and again at the end of 3 Henry VI when the future Richard III, echoing his father, exclaims of Margaret, "Why should she live, to fill the world with words?" (5.5.44). ${ }^{30}$ So Marlowe, in Lucans First Booke: "Filling the world, leaps out and throws forth fire" (154). Perhaps the two authors were remembering a Biblical figure of speech from Isaiah. He delivers "A prophecie against the kingdome of Satán, And of the ioye of the Church for their deliverance," according to the Geneva translators (1560): "Here after, Iaakób shal take rote: Israél shal florish and growe, and the worlde shal be filled with frute" (Is. 27.6). It might also be noted that Joan's "I prithee, give me leave to curse awhile" (1 Henry VI, 5.3.36) either echoes or foretells Constance's punning plea to the Pope's legate Pandulph in King John: "lawful let it be / That I have room with Rome to curse awhile" (3.1.179-80). For those keeping score, "curse" and its derivatives appear twice in King John, eleven times in 1 Henry VI. ${ }^{31}$

\footnotetext{
${ }^{29}$ The other instances include: "Pisanio might have kill'd thee at the heart" (Cymbeline, 4.2.322); "Blown with the windy tempest of my heart / Upon thy wounds, that kills mine eye and heart" (3 Henry VI, 2.5.86-87); "'twere no good part / To take on me to keep and kill thy heart" (Richard II, 5.1.98); "Out on thee, murderer! thou kill'st my heart" (Titus Andronicus, 3.2.54); "Offer me no money, I pray you, that kills my heart" (The Winter's Tale, 4.3.82-83).

${ }^{30}$ The quarto version of 3 Henry VI, The True Tragedie of Richard Duke of Yorke, features the line as well (London: Thomas Millington, 1600), sig. Hv.

${ }^{31}$ Spevack, Concordance, 1:72, 565, respectively.
} 
That the New Oxford Shakespeare attributed significant portions of Shakespeare's Henry VI plays to Marlowe furthers a sensible concept that needs advancing. Early modern dramatists were artisanal as well as artistic, and as craftsmen, they collaborated by necessity, the size of their enterprises demanding it, leaving scant space for our anachronistic notions of rivalry. This concept of teamwork relieves Shakespeare of his solitary splendour while valorising Marlowe by expanding his canon and joining him with his more esteemed colleague who survived and surpassed him. This association might encourage more and better scholarship about the interdependency of playwrights concerning textual production. ${ }^{32}$

Yet the New Oxford means of attribution, big-data analysis of function-word syntactic placement, creates an obstacle for itself as a tool for general use. Its laudable aim of authorial fingerprinting would appear to create foolproof results, but these methods cannot be accurately reproduced or challenged except by another computer program or formula. And unless a scholar regularly immerses herself in machinery of this kind, its many tabulations and percentages might seem inaccessible or useless for interpreting the texts whose words the algorithms have spun thus into diagrams, tables, and graphs. Should a means arise for investigating function-word similarities that does not require computer assessment, such likenesses would probably be invisible to the investigator, likely advised in advance that because of the impersonal authority of such data, the case, as they say, is closed. For this reason, the methodology appears to provide its adherents with what most academics secretly desire: the last word.

But the approach does not allow for human reading skill or ingenuity. The previouslycited derision of these talents as "old-fashioned parallel hunting" seems unnecessarily dismissive of the critical practice of inter- or intratextuality. Investigating multiplex correspondences between one author and another or a work by given writer and the rest of his canon ought not to be so cavalierly discounted. And it can only help a function-wordfrequency case for attribution if the disinterested reader may employ such techniques in discovering how authors or works could be in dialogue with one another. Graphs and tables are not enough.

1 Henry VI presents Joan as an oddly appealing figure, a tendency the playwright, whoever he was, inherited from the mysteries and the moral plays. Shakespeare implemented

\footnotetext{
${ }^{32}$ Roslyn L. Knutson made the most convincing case for the idea of collaboration in the early modern English public theatres. See Playing Companies and Commerce in Shakespeare's Time (Cambridge: Cambridge University Press, 2001). Another study often recommended about collaboration between early modern English playwrights is Heather Hirschfeld, Joint Enterprises: Collaborative Drama and the Institutionalization of the English Renaissance Theater (Amherst, MA: University of Massachusetts Press, 2004).
} 
it in notable antagonists: Iago, Edmund, Cassius, Suffolk. Or, to invoke Harley GranvilleBarker's unconventional definition of a hero: "the character of which a dramatist not morally, but artistically, most approves." 33 This observation almost always proves true for Marlowe in all his genres: Barabas, the Elegies speaker, the unreliable tale-teller who editorializes while narrating Hero and Leander, the epic voice of Lucan, Gaveston, Aeneas, Mephistophiles, and the ever-blank-versifying Tamburlaine. The dramatic members of this crew utter the phrases that best define them: "how sweet the bells ring now the nuns are dead" (The Jew of Malta, 4.1.2); "'Twas thine own seeking, Faustus. Thank thyself” (Dr Faustus, 1616, 2.3.4); "Musicians, that with touching of a string, / May draw the pliant King the way I please" (Edward II, 1.1.51-52); “must I rave thus for a runagate?” (Dido, Queen of Carthage 5.1.265); "peril is the chiefest way to happiness" (Massacre at Paris, 2.35); "What glory is there in a common good / That hangs for every peasant to achieve?" (37-38). Marlovian Joan similarly provides memorable poetry that illuminates her play like an arc light. Her confident declaration in its final act on the plains of Anjou shows her at her sententious, imperativedelivering best: "Of all base passions fear is most accurs'd. / Command the conquest, Charles, it shall be thine, / Let Henry fret and all the world repine" (1 Henry VI, 5.2.18-20). Succinct, subtly polished, humorous: Joan's lines rival Gloucester's before and after he becomes king. The eloquence of her entreaty to the men who will soon burn her alive, uttered between the interlude with the shepherd claiming paternity and the pathetic claim of pregnancy demonstrates the same characteristics:

I never had to do with wicked spirits.

But you, that are polluted with your lusts, Stain'd with the guiltless blood of innocents, Corrupt and tainted with a thousand vices, Because you want the grace that others have, You judge it straight a thing impossible To compass wonders but by help of devils. (5.4.42-48)

Joan begins with a colloquial declaration and then launches a formal and fluid multiclause attack addressed to her tormentors. Its appeal almost makes one forget the first section of the previous scene, in which she communes with the demonic, and which contradicts everything she asserts here, as if the playwright or playwrights had decided to conclude her part in the play in at least three different ways, and all survived in the First Folio: sorceress; purveyor of hypocritical complaints; or antagonistic yet truthful heroine. Yet 2 and 3 Henry VI

\footnotetext{
${ }^{33}$ Harley Granville-Barker, Prefaces to Shakespeare, 2 vols. (Princeton: Princeton University Press, 1947), $2: 351$.
} 
unquestionably validate Joan's assessment of York and Warwick, each a "setter-up and plucker-down of kings" (3 Henry VI, 2.2.37).

Those who have read Horace's great Actium ode know that though it was intended to please and honor Augustus and Agrippa, its real praise was for the unnamed and toxic Cleopatra, that enemy of the Empire, who burns through the poem like a comet. In its Marlovian antagonist, 1 Henry VI would seem to perform a similarly subversive maneuvre. It advances Joan to the most prominent position at play's end, one she occupies at its beginning: "Rescued is Orleans from the English: / Thus Joan la Pucelle hath peform'd her word" (1.6.2-3). She becomes dolphinlike, her back above her element, and in performing her word, embodies Horace's epithet for the unnamable Egyptian queen, "non humilis mulier" (Carmina, 1.37.32): not a base woman whatsoever. ${ }^{34}$

\section{Bibliography}

Bradbrook, M. C. “Shakespeare's Recollections of Marlowe.” In Shakespeare's Styles:

Essays in Honour of Kenneth Muir, edited by Philip Edwards, Inga-Stina Ewbank and G. K. Hunter, 199-204. Cambridge: Cambridge University Press, 1980.

Brooke, Nicholas. "Marlowe as Provocative Agent in Shakespeare's Early Plays." Shakespeare Survey 14 (1961): 34-44.

Brooks, Harold F. "Marlowe and Early Shakespeare.” In Christopher Marlowe, edited by Brian Morris, 65-94. London: Benn, 1968.

Burrow, Colin. "Shakespeare and Humanistic Culture." In Shakespeare and the Classics, edited by Charles Martindale and Tony B. Taylor, 9-27. Cambridge: Cambridge University Press, 2004.

Chambers, E. K. “The Disintegration of Shakespeare.” British Academy Annual Lecture (London: British Academy, 1924).

- William Shakespeare: A Study of Facts and Problems. 2 vols. Oxford: Clarendon, 1930.

Charney, Maurice. “The Voice of Marlowe's Tamburlaine in Early Shakespeare." Comparative Drama 31 (1997): 213-23.

Chernaik, Warren. "Shakespeare as Co-Author: The Case of 1 Henry VI." Medieval and Renaissance Drama in England 27 (2014): 192-220.

\footnotetext{
${ }^{34}$ Q. Horati Flacci Opera, ed. E. C. Wickham and H. W. Garrod, $2^{\text {nd }}$ ed. (Oxford: Clarendon Press, 1922), 31.
} 
Cox, John D. "Devils and Power in Shakespeare and Marlowe." Yearbook of English Studies 23 (1993): 46-64.

Craig, Hugh. "The Three Parts of Henry VI." In Shakespeare, Computers, and the Mystery of Authorship, edited by Hugh Craig and Arthur F. Kinney, 40-77. Cambridge: Cambridge University Press, 2009.

Crawford, Charles, ed. The Marlowe Concordance. Materialien zur Kunde des älteren englischen Dramas, 34 Bd. and Materials for the study of old English drama. 7 vols. Louvain: A. Uystpruyst, 1911-32.

DiCesare, Mario A. and Robert J. Fehrenbach, eds. A Concordance to the Plays, Poems and Translations of Christopher Marlowe. Ithaca, NY: Cornell University Press, 1982.

Fleay, Frederick. “Who Wrote Henry VI?” Macmillan's Magazine 33 (Nov. 1875): 50-62.

Garber, Marjorie. "Marlovian Vision / Shakespearean Revision.” Research Opportunities in Renaissance Drama 22 (1979): 3-9.

Granville-Barker, Harley. Prefaces to Shakespeare. 2 vols. Princeton: Princeton University Press, 1947.

Gray, Henry David. "The Purport of Shakespeare's Contribution to 1 Henry VI." PMLA 32, no. 3 (1917): 367-82.

Greenblatt, Stephen. "Shakespeare and the Exorcists." In Shakespeare and the Question of Theory, edited by Patricia Parker and Geoffrey Hartman, 163-87. New York: Routledge, 1985.

—. Shakespearean Negotiations. Oxford: Oxford University Press, 1988.

Gutierrez, Nancy. "Gender and Value in 1 Henry VI: The Role of Joan de Pucelle." Theatre Journal 42, no. 2 (1990): 183-93.

Henslowe, Philip. Henslowe's Diary, edited by W. W. Greg. 2 vols. London: A. H. Bullen, 1904.

Hirschfeld, Heather. Joint Enterprises: Collaborative Drama and the Institutionalization of the English Renaissance Theater. Amherst, MA: University of Massachusetts Press, 2004.

Holderness, Graham. Shakespeare: The Histories. New York: Palgrave Macmillan, 2000.

Horace. Q. Horati Flacci Opera, edited by E. C. Wickham and H. W. Garrod. $2^{\text {nd }}$ ed. Oxford: Clarendon Press, 1922.

Jackson, Gabriele Bernhard. “Topical Ideology: Witches, Amazons, and Shakespeare's Joan of Arc." English Literary Renaissance 18, no. 1 (1988): 63. 
Jackson, MacDonald P. “One-Horse Races: Some Recent Studies.” In The New Oxford Shakespeare Authorship Companion, edited by Gary Taylor and Gabriel Egan, 48-59. Oxford: Oxford University Press, 2017.

Knutson, Roslyn L. Playing Companies and Commerce in Shakespeare's Time. Cambridge: Cambridge University Press, 2001.

Lee, Jane. "On the Authorship of the Second and Third Parts of Henry VI, and Their Originals.” In The New Shakspere Society's Transactions, 1875-6, 219-79. London: Trübner and Co., 1876.

Levin, Harold. The Overreacher: A Study of Christopher Marlowe. Cambridge, MA: Harvard University Press, 1952.

Logan, Robert A. Shakespeare's Marlowe: The Influence of Christopher Marlowe on Shakespeare's Artistry. Burlington, VT: Ashgate, 2007.

Macdonald, Russ. "Marlowe and Style." In The Cambridge Companion to Christopher Marlowe, edited by Patrick Cheney, 55-69. Cambridge: Cambridge University Press, 2004.

Maguire, Laurie and Emma Smith. "What Is a Source? Or, How Shakespeare Read His Marlowe.” Shakespeare Survey 68 (2015): 15-31.

Marcus, Leah. Puzzling Shakespeare: Local Reading and Its Discontents. Berkeley, CA: University of California Press, 1988.

Marlowe, Christopher. Christopher Marlowe: The Complete Plays, edited by Mark Thornton Burnett. London: Dent, 1999.

- Christopher Marlowe: The Complete Poems, edited by Mark Thornton Burnett. London: Everyman, 2001.

Merriam, Thomas. "Tamburlaine Stalks in Henry VI." Computers and the Humanities 30 (1996): 267-91.

Muir, Kenneth. "Marlowe and Shakespeare." In “A Poet and a Filthy Play-maker": New Essays on Christopher Marlowe, edited by Kenneth Friedenreich, Roma Gill and Constance B. Kuriyama, 1-12. New York: AMS Press, 1988.

Nightingale, Benedict. "Henry VI, Stratford.” Theatre Review. New Statesman 94 (22 July 1977).

Ovid. P. Ovidi Nasonis Metamorphoses, edited by Richard J. Tarrant. Oxford: Clarendon Press, 2004.

Palmer, Henrietta Lee. The Stratford Gallery: Or, The Shakspeare Sisterhood. New York: Appleton, 1859. 
Petersen, William S. "Furnivall, Frederick James." Oxford Dictionary of National Biography, online edition. Oxford: Oxford University Press, 2007. First published online 2004.

Rackin, Phyllis. Stages of History: Shakespeare's English Chronicles. Ithaca, NY: Cornell University Press, 1990.

Ribner, Irving. “Marlowe and Shakespeare.” Shakespeare Quarterly 15, no. 2 (1964): 41-53.

Riggs, David. Shakespeare's Heroical Histories: "Henry VI" and Its Literary Tradition. Cambridge, MA: Harvard University Press, 1971.

Ryan, Patrick. "Shakespeare's Joan and the Great Whore of Babylon.” Renaissance and Reformation 28, no. 4 (2004): 55-82.

Schelling, Felix E. The English Chronicle Play: A Study in the Popular Historical Literature Environing Shakespeare. London: Macmillan, 1902.

Segerra, Santiago, Mark Eisen, Gabriel Egan, and Alejandro Ribeiro. "Attributing the Authorship of the Henry VI Plays by Word Adjacency.” Shakespeare Quarterly 67, no. 2 (2016): 232-56.

Shakespeare, William. The True Tragedie of Richard Duke of Yorke. London: Thomas Millington, 1600.

- The Works of Shakespeare, edited by Lewis Theobald. 7 vols. London: 1733.

- The Plays and Poems of William Shakespeare, edited by Edmund Malone. 10 vols. London: 1790.

- The Plays of William Shakespeare, edited by Samuel Johnson and George Steevens. 15 vols. London: 1793.

- The Leopold Shakspere, edited by Frederick James Furnivall. London: Cassell, Petter, and Galpin, 1877.

- The First Part of Henry the Sixth, edited by Henry Chichester Hart. London: Methuen, 1909.

The Riverside Shakespeare, edited by G. Blakemore Evans and J. J. M. Tobin, $2^{\text {nd }}$ ed. Boston, MA: Houghton Mifflin, 1997.

- The New Oxford Shakespeare: Modern Critical Edition: The Complete Works, edited by Gary Taylor, Teri Bourus, Gabriel Egan, and John Jowett. Oxford: Oxford University Press, 2016.

Shapiro, James. Rival Playwrights: Marlowe, Jonson, Shakespeare. New York: Columbia University Press, 1991.

Shaw, George Bernard. Saint Joan: A Chronicle Play in Six Scenes and an Epilogue. London: Constable, 1924. 
Spevack, Marvin, ed. A Complete and Systematic Concordance to the Works of Shakespeare. 9 vols. Georg Olms: Hildesheim, West Germany, 1968-80.

Swinburne, A. G. “The Three Stages of Shakespeare.” Fortnightly Review, n.s., 19 (Jan. 1876): 25-30.

Taylor, Gary. "Shakespeare and Others: The Authorship of Henry the Sixth, Part One." Medieval and Renaissance Drama in England 7 (1995): 145-205.

Taylor, Gary and John V. Nance. "Imitation or Collaboration? Marlowe and the Early Shakespeare Canon.” Shakespeare Survey 68 (2015): 32-47.

Thurn, David H. "Sovereignty, Disorder, and Fetishism in Marlowe's Edward II." Renaissance Drama 21 (1990): 115-41.

Tillyard, E. M. W. Shakespeare's History Plays. London: Chatto and Windus, 1944.

Vickers, Brian. "Incomplete Shakespeare: Or, Denying Co-Authorship in 1 Henry VI." Shakespeare Quarterly 58, no. 3 (2007): 311-57.

__. "Shakespeare and Authorship Studies in the Twenty-First Century." Shakespeare Quarterly 62, no. 1 (2011): 106-40.

Vincent, Paul. "Structuring and Revision in 1 Henry VI." Philological Quarterly 84, no. 4 (2005): 377-402.

Wilson, F. P. Marlowe and the Early Shakespeare. New York: Oxford University Press, 1953. 